\title{
The Use of "the Big Five" in Assessing Levels of Adaptation in Dental Students at Various Stages of Their Education
}

\author{
Larisa Litvinova ${ }^{1 *}$, Lyubov $^{\prime}$ Gubareva $^{2}$, Atsamaz Kaloyev ${ }^{1}$, and Yelena Grishilova ${ }^{1}$ \\ ${ }^{1}$ Stavropol State Medical University, 355010 Stavropol, Russia \\ ${ }^{2}$ North-Caucasus Federal University 355017 Stavropol, Russia
}

\begin{abstract}
Current approaches in psychology look at human adaptation reserves as part of individual character. "the Big Five" evaluates subjects' actual behaviour and levels of reserves of adaptation on each of the five scales. The results show reliably identifiable changes between the first and third years of study. Students acquire traits associated with introversion and reduce their social contacts $(\mathrm{p} \leq 0.01)$. A reduction to average is also visible in "Attachment - Detachment" $(\mathrm{p} \leq 0.05)$ and "Playfulness Practicality" $(p \leq 0.01)$. It can be seen that there is a reduction in the adaptation abilities of dental students between the first and third years in terms of social contact and the application of practical knowledge. Mastering the disciplines under study becomes harder, while the amount of theoretical knowledge and practical ability required increases, necessitating higher levels of concentration. Taking into account the increase in academic workload during this period, some of the above can be put down to stress.
\end{abstract}

\section{Introduction}

Developing well-being and raising the quality of life of a society hinge on the abilities of the country's university-educated professionals, which necessitates in turn a search for ways to improve their training. Research has shown that taking individual needs into account when designing educational programmes is reflected in the quality of the knowledge gained [1]. Workload at various stages of training and the adaptive capabilities of the students must also be acknowledged $[1,2]$.

Current approaches in psychology look at human adaptation reserves as part of individual character. The dispositional approach pioneered by Gordon Allport [3], which examines the structure of personality and enables psychologists to identify the dominant traits, was been selected as the method. Researchers take between three and 20 traits, usually compressing them into the well-known five-factor structure developed by Norman. The five comprise extraversion, agreeableness, conscientiousness, neuroticism and openness to experience [4], and were later named "the Big Five" by Goldberg (1981). They remain in use to this day.

\footnotetext{
${ }^{*}$ Corresponding author: larisa-litva@yandex.ru
} 
In addition to validity and simplicity of use, the method evaluates subjects' actual behaviour and levels of reserves of adaptation on each of the five scales. This results in an assessment of subjects' psycho-emotional condition, their effect on productivity and study and their potential in disparate categories, taking into account their individual characteristics [5].

Early adulthood is the time when people choose their careers and enter higher education. Every student goes through three periods of crisis: firstly, adaptation to a new social anvironment and to higher cognitive and psychological loads; secondly, their professional identity as a future doctor; and thirdly, adaptation to work as a graduate. The main aim of this reseach was to evaluate levels of reserves of adaptation during the first two periods of crisis.

\section{Materials and Methods}

An empirical investigation was conducted on students from the Dental Faculty of Stavropol State Medical University. The group comprised 24 first-year students and 14 third-year students. The Kh. Tsuyi Russian-language version of the Big Five was used as the test questionnaire. The results were statistically processed with Manna-Whitney U-criteria, which are used to assess probability in small groups.

\section{Results}

Statistical analysis of the data produced the following reliable and significant differences between first and third-year students (Table 1).

Table 1. Trends in Secondary Personal Characteristics in First and Third-Year Students.

\begin{tabular}{|c|c|c|c|c|c|}
\hline \multirow{2}{*}{ Scale } & \multicolumn{2}{|c|}{ First Year } & \multicolumn{2}{c|}{ Third Year } & \multirow{2}{*}{ Reliability } \\
\cline { 2 - 5 } & $\begin{array}{c}\text { Mean } \\
\text { value }\end{array}$ & $\begin{array}{c}\text { Standard } \\
\text { deviation }\end{array}$ & Mean value & $\begin{array}{c}\text { Standard } \\
\text { deviation }\end{array}$ & (p) \\
\hline $\begin{array}{c}\text { Extraversion - } \\
\text { Introversion }\end{array}$ & 55.00 & 10.30 & 45.43 & 11.67 & $\leq \mathbf{0 . 0 1 *}$ \\
\hline $\begin{array}{c}\text { Attachment - } \\
\text { Detachment }\end{array}$ & 58.25 & 9.03 & 49.43 & 14.51 & $\leq \mathbf{0 . 0 5 *}$ \\
\hline $\begin{array}{c}\text { Organised - } \\
\text { Easy-going }\end{array}$ & 58.00 & 9.89 & 49.64 & 16.30 & $>0.05$ \\
\hline $\begin{array}{c}\text { Emotional - } \\
\text { Reserved }\end{array}$ & 45.46 & 10.77 & 40.93 & 10.80 & $>0.05$ \\
\hline $\begin{array}{c}\text { Playfulness - } \\
\text { Practicality }\end{array}$ & 60.46 & 5.77 & 49.64 & 13.51 & $\leq \mathbf{0 . 0 1 *}$ \\
\hline
\end{tabular}

Note: ${ }^{*}-p<0.05$

The first figures illustrate the quantitive weight of the main factor. For a student with a high level of adaptation, having high scores in all five factors reflects a level of adaptation to both psychological and social expectations. This type of expectation reflects the accepted social behavioural norm and the ability of the student to either meet or fall out of it. A factor returning a middling or low score either highlights a "problem area" in social adaptation or reflects a personal temperamental quirk. 
The results show reliably identifiable changes between the first and third years of study in Extraversion - Introversion, Attachment - Detachment and Playfulness - Practicality. At the outset of their courses students have a ligh level of openness to the world, loyalty and the support of harmonious social connections, and also of inquisitiveness and interest in new information (both professional and everyday). By the third year extraversion levels have slumped to the lower edge of "average". Students acquire traits associated with introversion and reduce their social contacts $(\mathrm{p} \leq 0.01)$. A reduction to average is also visible in "Attachment - Detachment" $(p \leq 0.05)$ and "Playfulness - Practicality" $(p \leq 0.01)$. This is characterised by increased detachment within the student community, and the socially significant sense of rightness and high social status that membership of the medical profession confers begins to dominate.

\section{Discussion}

Third-year students' tendency toward introversion negatively affects their communication skills and ability to make new contacts. Their level of scialisation reduces, leading them to avoid participation in group work and unwillingness to work with all other members of the team. They become closed and lose trust in both strangers and people they know well. This type of behaviour tends to increase levels of anxiety, which negatively affects their participation in the process of education and their development as a whole.

The trend towards "Detachment" shows a reduced need to be near other people. Professionally, this is critical for future dentists. Medical staff need to be not only kind, but also as involved as possible in the pain, worries and problems of their patients and their patients' relatives. This influences both the quality of the treatment given and the results of therapy.

The increase in the level of "Practicality" among third-year dental students shows, on the one hand, their serious understanding of the process of education, and, on the other hand, the loss of essential traits such as curiosity, emotional openness and happiness. The reduction in "Playfulness - Practicality" scores does not affect the educational process, but does affect the quality of the knowledge gained and the ability to apply it as an intern.

It can be seen that there is a reduction in the adaptation abilities of dental students between the first and third years in terms of social contact and the application of practical knowledge. The formation of a realistic understanding of their surroundings and professional environment reduce their levels of trust and increase anxiety.

Taking into account the increase in academic workload during this period, some of the above can be put down to stress. Interest in study is lost, and despondency sets in, both in relation to home assignments and during class work. Mastering the disciplines under study becomes harder, while the amount of theoretical knowledge and practical ability required increases, necessitating higher levels of concentration. At the same time, as the conditions required to set in train a positive trend do not fully exist, it is necessary to take additional measures to increase resistance to stress in the face of the increasing workload.

\section{References}

1. Ye.R. Isayeva, Sovremennoye obrazovaniye: soderzhaniye, tekhnologii, kachestvo: Materialy XIX Mezhdunarod. nauch.-metod. konf., 24 apr. 2013, 15-17 (2013)

2. O.V. Pavlova, A.M. Shaporov, Ye.R. Isayeva, O.V. Tyusova, Psikhologiya - nauka budushchego: Materialy VI Mezhdunarod. konf. Molodykh uchenykh, 334-338 (2015)

3. G.W. Allport, Pattern and growth in personality (Holt, Rinehart and Winston, N.Y, 1961) 
4. G.W. Allport, The person in psychology: Selected essays (Beacon Press, Boston, 1968) 5. L.V. Litvinova, D.P. Nikulicheva, Zh.N. Sivtsova, Materialy II Vserossiyskoy nauchnoprakticheskoy konferentsii s mezhdunarodnym uchastiyem, 117-120 (2018) 